\title{
Multichannel charge separation promoted Zn0/P25 heterojunctions for the photocatalytic oxidation of toluene
}

\author{
Jiejing Kong a,c, Xiaodong Lai a , Zebao Rui b,c,*, Hongbing Ji a,c,\#, Shengfu Ji d \\ a School of Chemistry and Chemical Engineering, Sun Yat-sen University, Guangzhou 510275, Guangdong, China \\ b School of Chemical Engineering and Technology, Sun Yat-sen University, Guangzhou 510275, Guangdong, China \\ ' $R \& D$ Center of Waste-Gas Cleaning and Control, Huizhou Research Institute of Sun Yat-sen University, Huizhou 516081, Guangdong, China \\ d State Key Laboratory of Chemical Resource Engineering, Beijing University of Chemical Technology, Beijing 100029, China
}

\section{A R T I C L E I N F O}

\section{Article history:}

Received 22 January 2016

Accepted 29 March 2016

Published 5 June 2016

\section{Keywords:}

Titanium dioxide

Zinc oxide

Toluene

Photocatalysis

Heterojunction

Multichannel charge separation

\begin{abstract}
A B S T R A C T
The fabrication of multicomponent heterojunctions is an effective strategy to improve the performance of $\mathrm{TiO}_{2}$ based photocatalysts. We provide a new strategy for improving the charge separation and photocatalytic performance of $\mathrm{ZnO} \mathrm{TiO}_{2}$ composites by the formation of multichannel charge separated heterojunctions. ZnO/P25 composites were prepared by an incipient wetness impregnation method, and applied for the photocatalytic destruction of gaseous toluene. The $\mathrm{ZnO} / \mathrm{P} 25 \mathrm{com}$ posites consist of anatase $\mathrm{TiO}_{2}\left(\mathrm{ATiO}_{2}\right)$, rutile $\mathrm{TiO}_{2}\left(\mathrm{RTiO}_{2}\right)$ and hexagonal zincite structures. The parasitic phase of $\mathrm{ZnO}$ in $\mathrm{P} 25$ leads to the formation of $\mathrm{ZnO}(002) / \mathrm{ATiO}_{2}(101) / \mathrm{RTiO}_{2}(110)$ heterojunctions that exhibit enhanced light absorption and improved multichannel electron/hole separation. $\mathrm{ZnO} / \mathrm{P} 25$ heterojunctions can completely oxidize toluene into $\mathrm{CO}_{2}$ and $\mathrm{H}_{2} \mathrm{O}$ under ultraviolet light irradiation at room temperature, and show enhanced photocatalytic activity in comparison with P25 owing to the efficient electron-hole separation. Such a multichannel charge separated design strategy may provide new insight into the design of highly effective photocatalysts and their potential technological applications.
\end{abstract}

(C) 2016, Dalian Institute of Chemical Physics, Chinese Academy of Sciences. Published by Elsevier B.V. All rights reserved.

\section{Introduction}

Toluene is one of the most common toxic volatile organic compounds in an indoor environment, which is emitted from decoration materials, paint and cementing compounds, and poses a potential health risk to human beings even at a very low concentration level [1]. Recently, many methods have been proposed to remove trace toluene from air, such as adsorption [2], catalytic oxidation [3-5] and photocatalysis [6,7]. Among them, photocatalytic oxidation is one of the most effective and economically feasible technologies because toluene can be photodegraded into $\mathrm{CO}_{2}$ over photocatalysts under mild conditions.

$\mathrm{TiO}_{2}$ has been one of the most widely studied photocatalysts for environmental applications, such as air purification and water purification, owing to its practicality and superior oxidation capability $[8,9]$. $\mathrm{TiO}_{2}$ is usually used as a photocatalyst in two crystal structures: anatase $\mathrm{TiO}_{2}\left(\mathrm{ATiO}_{2}\right)$ and rutile $\mathrm{TiO}_{2}$ $\left(\mathrm{RTiO}_{2}\right)$. However, both of them suffer from a low quantum yield in their technical application owing to the rapid recombi-

\footnotetext{
* Corresponding author. Tel: +86-20-84113663; E-mail: ruizebao@mail.sysu.edu.cn

\# Corresponding author. Tel: +86-20-84113658; E-mail: jihb@mail.sysu.edu.cn

This work was supported by the National Natural Science Foundation of China $(21576298,21425627)$, the Science and Technology Plan Project of Guangdong Province (2013B090500029), and Natural Science Foundation of Guangdong Province (2014A030313135, 2014A030308012), and the State Key Laboratory of Chemical Resource Engineering (CRE-2015-C-301), China.

DOI: 10.1016/S1872-2067(15)61093-2 | http://www.sciencedirect.com/science/journal/18722067 | Chin. J. Catal., Vol. 37, No. 6, June 2016
} 
nation of photo-induced electron-hole pairs [10]. Recently, various modifications have been performed that have focused on overcoming this barrier, including noble metal decoration $[11,12]$ and the fabrication of multicomponent heterojunctions $[13,14]$. Various heterostructures have been reported to suppress the recombination of carriers, such as $\mathrm{TiO}_{2} /$ graphene [15], $\mathrm{CdS} / \mathrm{TiO}_{2}$ [16], $\mathrm{TiO}_{2} / \mathrm{SnO}_{2}$ [17], $\mathrm{Ag}_{2} \mathrm{CO}_{3} / \mathrm{TiO}_{2}$ [18] and $\mathrm{ZnO} / \mathrm{TiO}_{2}$ [19-25]. Among them, the combination of wurtzite $\mathrm{ZnO}$ with $\mathrm{ATiO}_{2}$ has received particular attention because of the enhanced photocatalytic performance of $\mathrm{ZnO} / \mathrm{ATiO}_{2}$ and the low cost, non-toxic and high photocatalytic properties of $\mathrm{ZnO}$ [19]. The enhancement is ascribed to the formation of heterojunctions in the interface between $\mathrm{ZnO}$ and $\mathrm{ATiO}_{2}$ and its function on the photo-induced electron-hole separation. Although the binding energies of $\mathrm{ZnO}$ and $\mathrm{TiO}_{2}$ are analogous to each other, the potentials of the conduction band (CB) and the valence band (VB) of $\mathrm{ZnO}$ are still a little more negative than those of $\mathrm{TiO}_{2}$ [20]. The electron transfer from the $\mathrm{CB}$ of $\mathrm{ZnO}$ to the $\mathrm{CB}$ of $\mathrm{TiO}_{2}$ and the hole transfer from the $\mathrm{VB}$ of $\mathrm{TiO}_{2}$ to the $\mathrm{VB}$ of $\mathrm{ZnO}$ proceed under illumination. As a result, the increase in the availability of the charges on the photocatalyst surface and consequently an improvement of the photocatalytic process can be expected. Kim et al. [21] reported that the photocurrent and the resulting photocatalytic properties of phenol decreased as the thickness of the $\mathrm{ZnO}$ layer increased in $\mathrm{ZnO} / \mathrm{TiO}_{2}$ nanoporous films, which was understood in terms of the function of $\mathrm{ZnO} / \mathrm{TiO}_{2}$ heterojunctions on the charge carrier lifetime. Moreover, as $\mathrm{ZnO}$ serves as excellent channels outstretched directly from $\mathrm{ATiO}_{2}$ for the holes, the photocorrosion of $\mathrm{ZnO}$ is inhibited efficiently and the photostability of the $\mathrm{ZnO} / \mathrm{ATiO}_{2}$ hierarchical hybrid nanostructures can be enhanced [22].

To promote the charge separation and the photocatalytic performance of $\mathrm{ZnO} / \mathrm{ATiO}_{2}$, various $\mathrm{ZnO} / \mathrm{ATiO}_{2}$ hybrid nanostructures with hierarchical morphology have been designed [19-25]. Chen et al. [23] prepared $\mathrm{ZnO} / \mathrm{ATiO}_{2}$ nanocomposites using a hydrothermal method. Xiao [24] fabricated three-dimensional arrayed $\mathrm{ZnO} / \mathrm{ATiO}_{2}$ nanotube heterostructure by a two-step anodization combined with a pyrolysis approach. Wu et al. [25] fabricated ZnO-nanorod framed $\mathrm{ZnO} / \mathrm{ATiO}_{2}$ heterostructures through a face-selective growth process, in which uniform $\mathrm{ZnO}$ nanorod arrays covered all eight $\{101\}$ faces, while the two highly reactive $\{001\}$ faces remained untouched. It was demonstrated that the photocatalytic performance of these coupled $\mathrm{ZnO}^{-\mathrm{ATiO}_{2}}$ hierarchical hybrid nanostructures was enhanced to some extent owing to their unique heterostructures. However, owing to the synthetic complexity of the hybrid nanostructures and limited improvement in the charge separation by the morphology modification, the design of effective heterostructures for photocatalytic application, such as $\mathrm{ZnO} / \mathrm{TiO}_{2}$, continues to be a challenge.

Herein, we provide a new strategy for improving the charge separation and photocatalytic performance of $\mathrm{ZnO} / \mathrm{TiO}_{2}$ by the formation of multichannel charge separation promoted heterojunctions. $\mathrm{ZnO} / \mathrm{TiO}_{2}$ (P25) composites with different $\mathrm{ZnO}$ contents and calcination temperatures were synthesized by a facile incipient wetness impregnation method and applied for the photocatalytic destruction of gaseous toluene. P25, consisting of anatase and rutile $(4 / 1, w / w)$, has frequently been used as a benchmark for photocatalysts $[10,26]$. The parasitic phase of $\mathrm{ZnO}$ in P25 leads to the formation of $\mathrm{ZnO}(002) / a n a-$ tase(101)/rutile(110) junctions and enhances the light absorption. Especially, the multichannels for electron/hole separation in the as-formed heterojunctions remarkably improve the charge separation and photocatalytic performance of $\mathrm{ZnO} / \mathrm{P} 25$ in comparison with P25.

\section{Experimental}

\subsection{Catalyst preparation}

$\mathrm{ZnO} / \mathrm{TiO}_{2}$ (P25) composites were synthesized through the incipient wetness impregnation method. In a typical preparation experiment, P25 (Degussa) was uniformly dispersed into the aqueous solution containing the requisite amount of $\mathrm{Zn}\left(\mathrm{CH}_{3} \mathrm{COO}\right)_{2} \cdot 2 \mathrm{H}_{2} \mathrm{O}$ (Sinopharm Chemical Reagent Co., Ltd., China) to obtain a $\mathrm{ZnO}$ loading amount of $0.1,0.5$ or $1 \mathrm{wt} \%$. The samples were then dried at $120{ }^{\circ} \mathrm{C}$ overnight to evaporate the solvent and finally calcined at 300,500 , or $700{ }^{\circ} \mathrm{C}$ for $6 \mathrm{~h}$ with a heating rate of $10{ }^{\circ} \mathrm{C} / \mathrm{min}$ in air, respectively. For comparison, $\mathrm{ZnO}$ powder was obtained by calcining $\mathrm{Zn}\left(\mathrm{CH}_{3} \mathrm{COO}\right)_{2} \cdot 2 \mathrm{H}_{2} \mathrm{O}$ at $500{ }^{\circ} \mathrm{C}$ for $6 \mathrm{~h}$ with a heating rate of $10^{\circ} \mathrm{C} / \mathrm{min}$ in air. Some P25 powder was also calcined at $500{ }^{\circ} \mathrm{C}$ for $6 \mathrm{~h}$ with a heating rate of $10{ }^{\circ} \mathrm{C} / \mathrm{min}$ in air for reference (P25-500). The as-prepared catalysts were respectively denoted as $\mathrm{ZnO} / \mathrm{P} 25$ with the $\mathrm{ZnO}$ loading amount number in front and the calcination temperature behind for simplicity.

\subsection{Catalyst characterization}

The phase purity and crystal structure of the samples were examined by X-ray diffraction (XRD) using a D-MAX diffractometer with $\mathrm{Cu} K_{\alpha}$ radiation at a scanning rate of $10^{\circ} / \mathrm{min}$ and a step size of $0.02^{\circ}$. The Brunauer-Emmett-Teller (BET) surface area, pore volume and pore size distribution of the samples were measured with a Micromeritics ASAP 2020 instrument using $\mathrm{N}_{2}$ adsorption-desorption at $-196{ }^{\circ} \mathrm{C}$. Prior to the measurement, the samples were degassed at $300{ }^{\circ} \mathrm{C}$ for $3 \mathrm{~h}$. The morphologies and compositions of the samples were analyzed by transmission electron microscopy (TEM \& HRTEM, JEM2010-HR). The ultraviolet (UV)-visible diffuse reflectance spectra were measured using a UV-visible spectrophotometer (DRS, UV2450) with an integrating sphere attachment. The photoluminescence properties were characterized by a combined fluorescence lifetime and steady state spectrometer (PL, FLSP920) with a xenon lamp (excitation wavelength $350 \mathrm{~nm}$ ) as a light source. Photocurrents were measured by an electrochemical analyzer (CHI660E Instruments) in a standard three-electrode system with the as-prepared samples as the working electrodes with an active area of approximately 0.5 $\mathrm{cm}^{2}$, a Pt wire as the counter electrode, and $\mathrm{Ag} / \mathrm{AgCl}$ (saturated $\mathrm{KCl})$ as a reference electrode. A 300-W Xe lamp equipped with a UV reflector $(\lambda=300-400 \mathrm{~nm}$, optical power density is 200 $\mathrm{mW} / \mathrm{cm}^{2}$ ) was used as the UV-light source. $\mathrm{N}_{2}$-saturated 0.1 
$\mathrm{mol} / \mathrm{L} \mathrm{NaOH}$ in water was used as the electrolyte.

\subsection{Photocatalytic activity evaluation}

Photocatalytic degradation of toluene over the as-prepared catalysts was performed in a stainless-steel reactor with a quartz window on the top of the reactor. The reaction vessel was evacuated and backfilled with a gas mixture of $\mathrm{O}_{2}, \mathrm{~N}_{2}$ $\left(\mathrm{O}_{2}: \mathrm{N}_{2}=1: 3\right)$ and trace toluene. Vaporous toluene was injected by flowing the simulated air into a saturator that was filled with toluene solution before entering the vessel. Prior to visible-light irradiation, the reaction vessel was kept in the dark for $2 \mathrm{~h}$ until an adsorption-desorption equilibrium was established. The initial concentration of gaseous toluene was $\sim 500 \mathrm{ppm}$, and the relative humidity in the reactor was approximately $16 \%$. The light source was a 300-W Xe lamp equipped with a UV reflector $\left(\lambda=300-400 \mathrm{~nm}\right.$, optical power density is $\left.200 \mathrm{~mW} / \mathrm{cm}^{2}\right)$. An aliquot of $0.2 \mathrm{~g}$ catalyst powder was suspended in deionized water to disperse in a quartz reaction vessel with an irradiation area of $7.0 \mathrm{~cm}^{2}$, and then dried at $70{ }^{\circ} \mathrm{C}$ in air overnight before photocatalytic test. The photocatalytic reaction was typically carried out under atmospheric pressure at room temperature for $120 \mathrm{~min}$. The atmospheric composition in the reaction vessel was analyzed with a gas chromatography system (GC7900, Tianmei, China), which was equipped with a flame ionization detector (FID). The $\mathrm{CO}_{2}$ formation amount was measured by another gas chromatograph (GC2060, FID) equipped with a nickel catalyst-based methanizer with a flame ionization detector. The performance of the photocatalyst was evaluated by the $\mathrm{CO}_{2}$ formation rate, and the removal of toluene was calculated by using the following equation:

$$
\text { Conversion }=\left(n_{\mathrm{co}, 2, t} / 7\right) / n_{\text {tol }, 0} \times 100 \%
$$

where $n_{\mathrm{tol}, 0}$ is the initial molar quantity of gaseous toluene in the reactor, and $n n_{\mathrm{CO} 2, t}$ is the gaseous $\mathrm{CO}_{2}$ molar quantity at irradiation time $(t)$.

\section{Results and discussion}

\subsection{Structural properties}

Fig. 1(a) displays the XRD patterns of commercial P25 and $\mathrm{ZnO} / \mathrm{P} 25$ samples calcined at $500{ }^{\circ} \mathrm{C}$ with different $\mathrm{ZnO}$ loadings. As presented, commercial P25 contains both the tetragonal anatase structured $\mathrm{TiO}_{2}$ (JCPDS 21-1272) and tetragonal rutile $\mathrm{TiO}_{2}$ (JCPDS 21-1276). For the ZnO/P25-500 samples, except for the characteristic peaks assigned to $\mathrm{ATiO}_{2}$ and $\mathrm{RTiO}_{2}$, the hexagonal zincite phase (ZnO, JCPDS 36-1451) is detected, and the intensity of its characteristic peaks increases with the increase in the $\mathrm{ZnO}$ loading. Since the phase transform from anatase to rutile may happen upon calcination $[27,28]$, the relative amount of $\mathrm{ATiO}_{2}$ and $\mathrm{RTiO}_{2}$ in the samples was estimated by calculating the diffraction peak intensity ratio $I_{\mathrm{A}} / I_{\mathrm{R}}$ of $\mathrm{ATiO}_{2}$
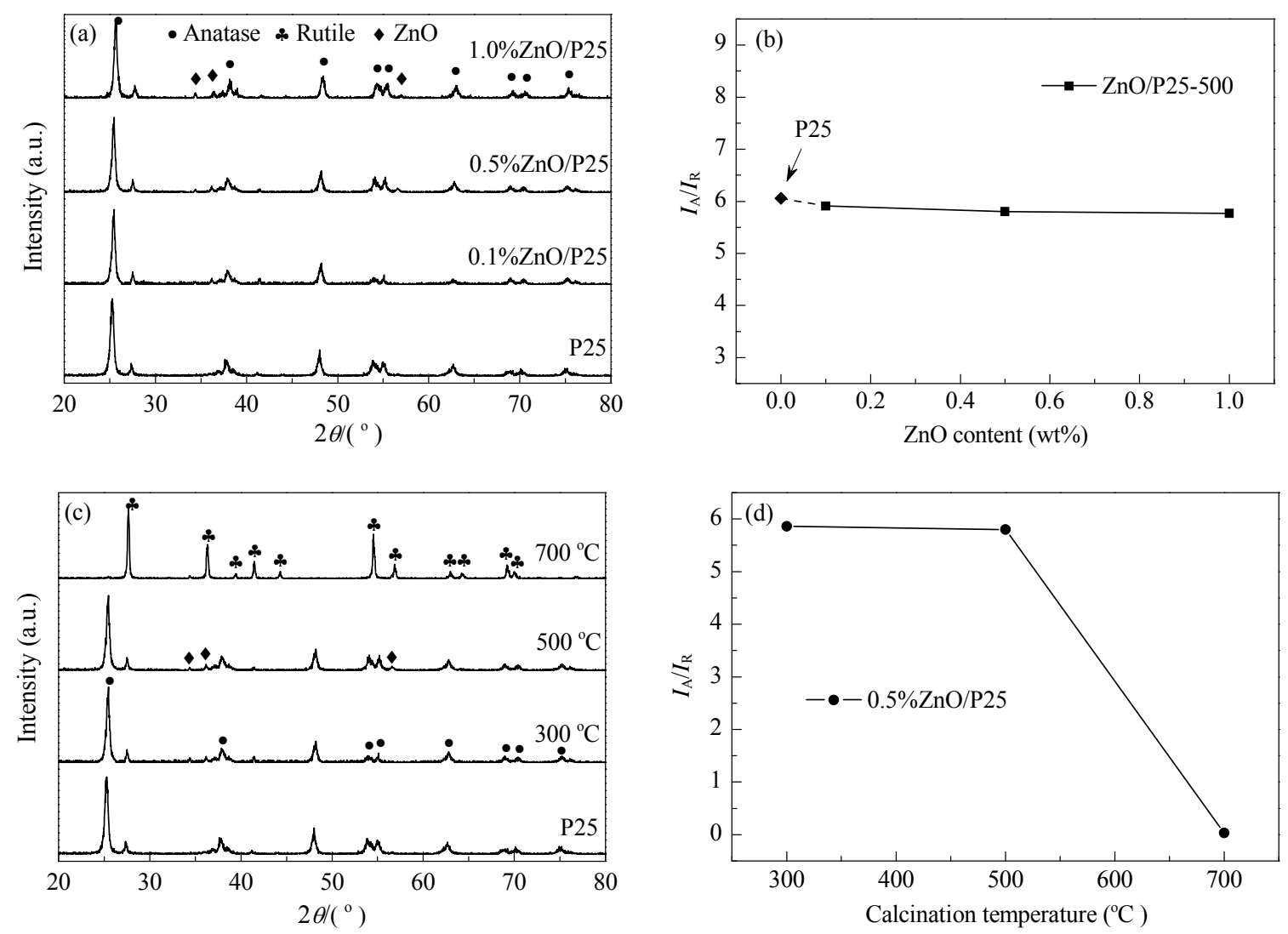

Fig. 1. XRD patterns of $\mathrm{ZnO} / \mathrm{P} 25$ composites calcined at $500{ }^{\circ} \mathrm{C}$ with different $\mathrm{ZnO}$ loads (a) and $0.5 \% \mathrm{ZnO} / \mathrm{P} 25$ calcined at different temperatures (c); the corresonding diffraction peak intensity ratios of $\mathrm{ATiO}_{2}\left(2 \theta=25.3^{\circ}\right)$ to $\mathrm{RTiO}_{2}\left(2 \theta=27.4^{\circ}\right)$ in these samples $(\mathrm{b}, \mathrm{d})$. The pattern of $\mathrm{P} 25 \mathrm{is}$ listed as a reference. 
$\left(2 \theta=25.3^{\circ}\right)$ to $\mathrm{RTiO}_{2}\left(2 \theta=27.4^{\circ}\right)$. As presented in Fig. $1(\mathrm{~b})$, the $I_{\mathrm{A}} / I_{\mathrm{R}}$ values of the $\mathrm{ZnO} / \mathrm{P} 25-500$ samples are all close to that of P25, indicating no obvious phase change in the P25 support occurs upon ZnO loading and the subsequent calcination at 500 ${ }^{\circ} \mathrm{C}$. Fig. 1 (c) shows the XRD patterns of $0.5 \% \mathrm{ZnO} / \mathrm{P} 25$ calcined at different temperatures, and Fig. $1(\mathrm{~d})$ is the corresponding relationship between the $I_{\mathrm{A}} / I_{\mathrm{R}}$ values and the calcination temperature of the $0.5 \% \mathrm{ZnO} / \mathrm{P} 25$ samples. As presented, these samples all consist of $\mathrm{ATiO}_{2}, \mathrm{RTiO}_{2}$ and $\mathrm{ZnO}$ phases, and no obvious change in their composition can be detected when the calcination temperature increases from 300 to $500{ }^{\circ} \mathrm{C}$. However, at a high calcination temperature of $700{ }^{\circ} \mathrm{C}$, a serious phase change from $\mathrm{ATiO}_{2}$ to $\mathrm{RTiO}_{2}$ proceeds, and a little $\mathrm{ATiO}_{2}$ can be detected in 0.5\%ZnO/P25-700.

The BET surface area, average pore size and pore volume of commercial P25 and 0.5\%ZnO/P25 calcined at different temperatures are listed in Table 1 . As shown, upon loading of $0.5 \% \mathrm{ZnO}$ and calcining at $300{ }^{\circ} \mathrm{C}$, the pore volume and pore size of $0.5 \% \mathrm{ZnO} / \mathrm{P} 25-300$ are larger than those of the commercial P25 powder. This phenomenon is probably because of the crystallization of the amorphous phase in P25 during this process, which may open (or create) some plugged pores along with the blockage of the small pores by the Zn species and sintering. As a result, no obvious BET-area change between P25 and $0.5 \% \mathrm{ZnO} / \mathrm{P} 25-300$ is observed. The existence of the minor amorphous phase aside from the main $\mathrm{ATiO}_{2}$ and $\mathrm{RTiO}_{2}$ in P25 was demonstrated previously by Ohtani et al. [29]. Both the BET-area and pore volume of $0.5 \% \mathrm{ZnO} / \mathrm{P} 25$ decrease with further increasing calcination temperature, which is more remarkable for $0.5 \% \mathrm{ZnO} / \mathrm{P} 25-700$. The serious sintering in $0.5 \%$ $\mathrm{ZnO} / \mathrm{P} 25-700$ upon calcinating at $700{ }^{\circ} \mathrm{C}$ relates to the transformation from the anatase to rutile phase [28,30]. Amores et al. [30] proposed that the time needed for the sintering of the rutile particles produced by the anatase phase transformation was shortened owing to the heat produced by the phase transformation itself, which they termed as 'phase transformation-induced sintering'. TEM and HRTEM images of $0.5 \% \mathrm{ZnO} / \mathrm{P} 25-500$ are displayed in Fig. 2. As shown, $0.5 \% \mathrm{ZnO} / \mathrm{P} 25-500$ is mainly composed of irregular nanoparticles with a diameter of 20-50 nm. HRTEM image in Fig. 2(b) clearly shows that the sample is composed of $\mathrm{ATiO}_{2}, \mathrm{RTiO}_{2}$ and $\mathrm{ZnO}$ phases, and the heterojunction structure among the anatase (101), rutile (110) and $\mathrm{ZnO}(002)$ is formed.
Table 1

BET surface area $(A)$, average pore size $(D)$ and pore volume $(V)$ of samples.

\begin{tabular}{lccc}
\hline Sample & $A\left(\mathrm{~m}^{2} / \mathrm{g}\right)$ & $D^{\mathrm{a}}(\mathrm{nm})$ & $V^{\mathrm{b}}\left(\mathrm{cm}^{3} / \mathrm{g}\right)$ \\
\hline P25 & 55 & 12.0 & 0.17 \\
0.5\%ZnO/P25-300 & 55 & 24.7 & 0.44 \\
0.5\%ZnO/P25-500 & 39 & 24.3 & 0.41 \\
0.5\%ZnO/P25-700 & 9 & 35.2 & 0.11 \\
\hline
\end{tabular}

${ }^{\mathrm{a} B J H}$ desorption average pore width. ${ }^{\mathrm{b}} \mathrm{BJH}$ desorption pore volume for the $1.7-300 \mathrm{~nm}$ range of pore diameters.

\subsection{Optical properties}

Fig. 3 presents the UV-vis diffuse reflectance spectra (DRS) of P25 and $\mathrm{ZnO} / \mathrm{P} 25$ with various $\mathrm{ZnO}$ loadings and calcination temperatures, which show the photo-absorption in the UV light region for all the samples. Generally, the loading of $\mathrm{ZnO}$ enhances the photo-absorption of P25. Among these samples, 0.5\%ZnO/P25-500 holds the strongest photo-absorption. The optical band gaps $\left(E_{\mathrm{g}}\right)$ of the samples can be estimated by using the following equation [31]:

$$
\alpha h v=C\left(h v-E_{\mathrm{g}}\right)^{n}
$$

Herein, $h v$ is the photon energy, $\alpha$ is the absorption coefficient, and $C$ is a constant. $n$ is determined by the type of optical transition of the semiconductor and also depends on the polymorph (i.e., $n=1 / 2$ for direct transition and $n=2$ for indirect transition). Here, we used $n=2$ for all the samples. The optical band gap values, estimated from the insets in Fig. 3(a) and (b), are shown in Table 2. As shown, a slight red shift to the visible-light region is observed for these $\mathrm{ZnO} / \mathrm{P} 25$ samples in comparison with the band gap of P25 (3.16 eV). In addition, the shift value increases with an increase of the calcination temperature. Because the phase transformation from $\mathrm{ATiO}_{2}$ to $\mathrm{RTiO}_{2}$ in the composites is more serious at a high temperature and the band gap of $\mathrm{RTiO}_{2}$ is narrower than that of $\mathrm{ATiO}_{2}$, the red shift in the $\mathrm{ZnO} / \mathrm{P} 25$ composites is expected with an increase of the calcination temperature.

PL spectra are regarded as an effective approach to evaluate the separation efficiency of the photo-induced carriers [32]. As seen in Fig. 4(a) and (b), the emission centered at $468 \mathrm{~nm}$ is attributed to the radiative recombination of a hole in the valence band and an electron in the conduction band (near band emission, NBE). As shown, the NBE peak intensity of all the
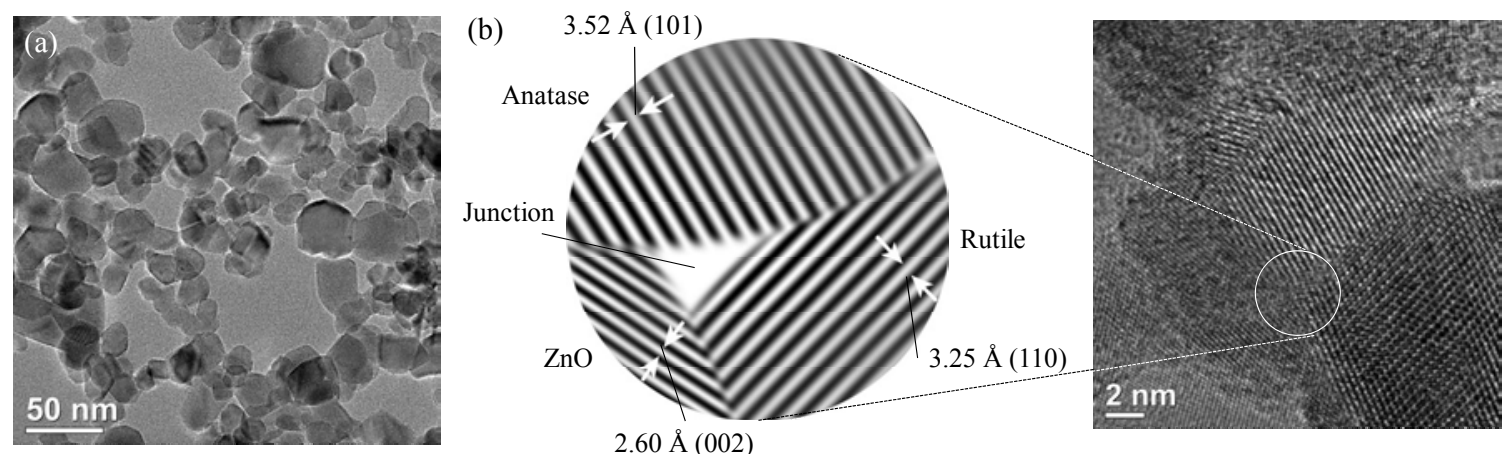

Fig. 2. TEM (a) and HRTEM (b) images of 0.5\% ZnO/P25-500. 

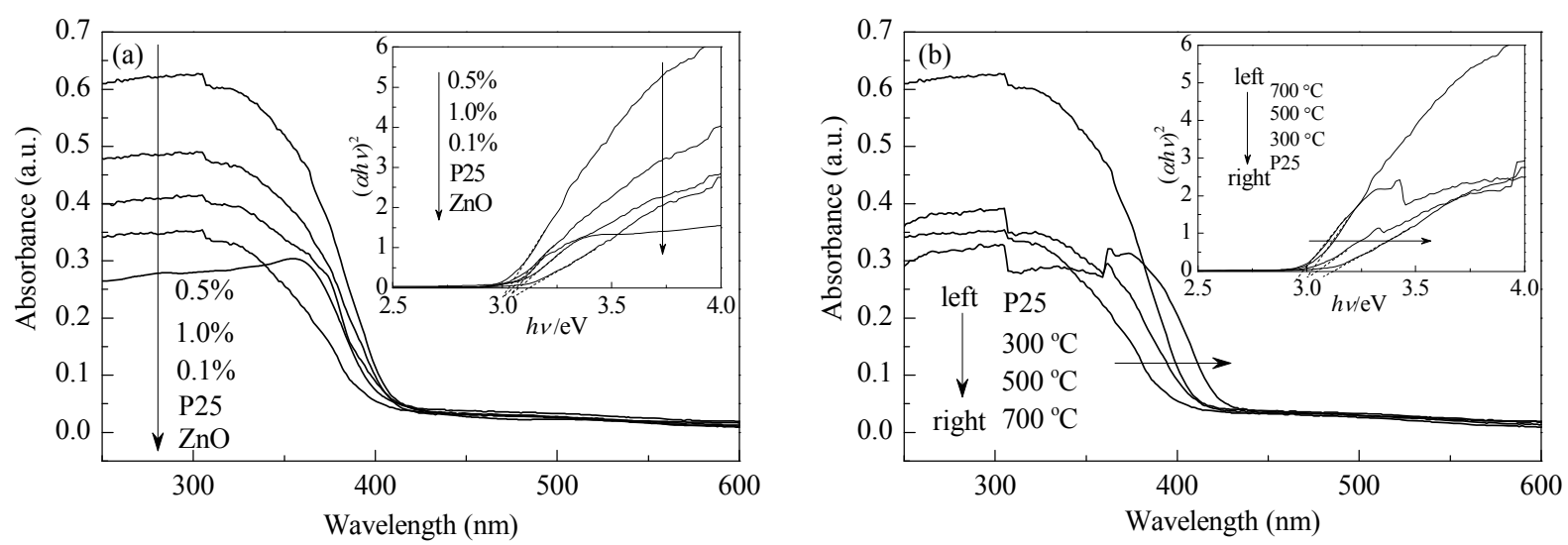

Fig. 3. UV-vis diffuse reflectance spectra of $\mathrm{ZnO} / \mathrm{P} 25$ composites calcined at $500{ }^{\circ} \mathrm{C}$ with various $\mathrm{ZnO}$ loadings (a) and $0.5 \% \mathrm{ZnO} / \mathrm{P} 25 \mathrm{calcined}$ at various temperatures (b). Insets show the dependence of $(\alpha h v)^{2}$ on the photon energy.

Zn0/P25 samples is clearly lower than that of P25, among which the peak of $0.5 \% \mathrm{ZnO} / \mathrm{P} 25-500$ is the lowest. These results indicate that the modification of P25 by minor $\mathrm{ZnO}$ can efficiently improve the photo-induced charge separation, and this improvement is more prominent in 0.5\% $\mathrm{ZnO} / \mathrm{P} 25-500$. Photo-electrochemical properties of P25 and $0.5 \% \mathrm{ZnO} /$ P25-500 thin films were further used to detect their transient photocurrent responses and the electron-hole separation and transfer difference. The photocurrent $(I)$-time $(t)$ responses of P25 and 0.5\%ZnO/P25-500 with several on-off cycles under UV light irradiation are shown in Fig. 4(c). As indicated, both samples generate photocurrents with a reproducible response to on-off cycles under UV light irradiation, demonstrating the

Table 2

Estimated band gap values of commercial $\mathrm{P} 25, \mathrm{ZnO}$ and $\mathrm{ZnO} / \mathrm{P} 25$ heterojunctions with various $\mathrm{ZnO}$ loadings and calcination temperatures.

\begin{tabular}{lc}
\hline Sample & $E_{\mathrm{g}} / \mathrm{eV}$ \\
\hline P25 & 3.16 \\
$\mathrm{ZnO}$ & 3.10 \\
$0.1 \% \mathrm{ZnO} / \mathrm{P} 25-500$ & 3.08 \\
$0.5 \% \mathrm{ZnO} / \mathrm{P} 25-300$ & 3.08 \\
$0.5 \% \mathrm{ZnO} / \mathrm{P} 25-500$ & 3.04 \\
$0.5 \% \mathrm{ZnO} / \mathrm{P} 25-700$ & 2.95 \\
$1.0 \% \mathrm{ZnO} / \mathrm{P} 25-500$ & 3.06 \\
\hline
\end{tabular}

effective charge transfer and electron collection for the photoelectrodes. The photocurrent density of $0.5 \% \mathrm{ZnO} / \mathrm{P} 25-500$ is approximately $210 \mu \mathrm{A} / \mathrm{cm}^{2}$, which is considerably larger than that of P25 $\left(\sim 78 \mu \mathrm{A} / \mathrm{cm}^{2}\right)$. The obvious photocurrent enhancement of 0.5\%ZnO/P25-500 indicates more efficient UV light absorption and separation of photo-induced electrons/ holes of the charge carrier at the interface, which is consistent with the DRS and PL analysis above. Moreover, there is no obvious decrease in the photocurrent density after 4 cycles of on-off UV exposure, indicating the good stability of the 0.5\%ZnO/P25-500 photo-electrode.

\subsection{Photocatalytic performance}

The as-synthesized samples were then evaluated for the photocatalytic degradation of toluene in a batch reactor under UV irradiation $(\lambda=300-400 \mathrm{~nm})$. Fig. 5(a) shows that all the $\mathrm{ZnO} / \mathrm{P} 25$ samples calcined at $500{ }^{\circ} \mathrm{C}$ can completely convert toluene into $\mathrm{CO}_{2}$ after UV-light illumination for $2 \mathrm{~h}$, and 0.5\%ZnO/P25-500 exhibits the highest photocatalytic degradation rate. As a reference, the performance of P25 powder after the same calcination process is also provided in Fig. 5(a), which shows a significantly lower photocatalytic degradation rate than that of $0.5 \% \mathrm{ZnO} / \mathrm{P} 25-500$.
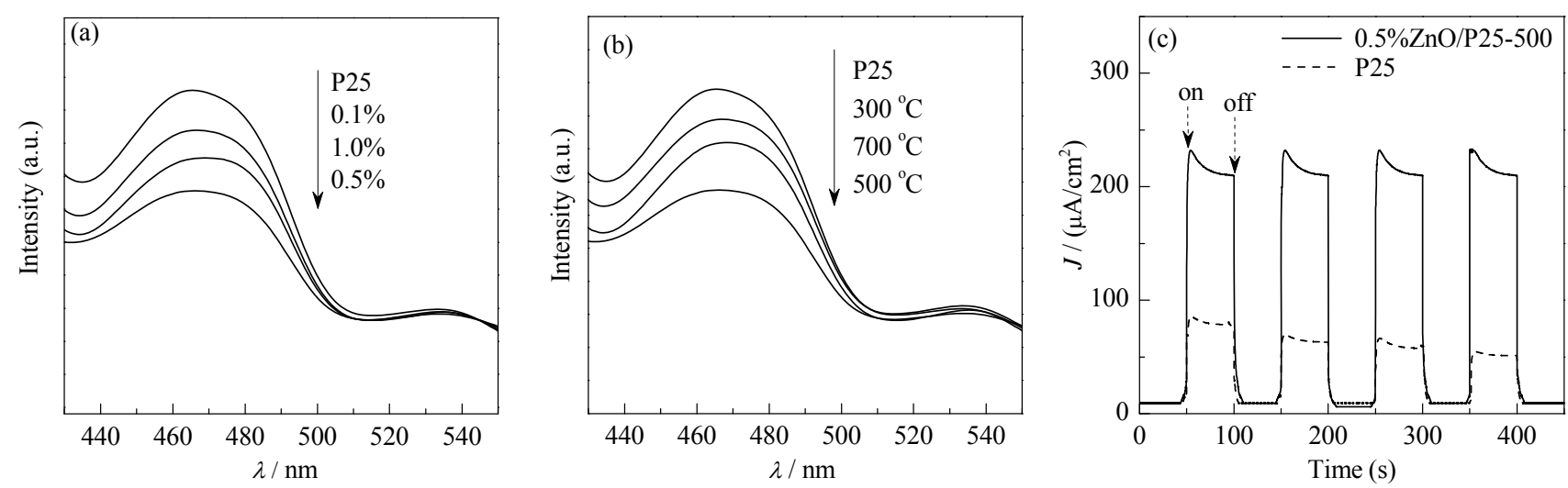

Fig. 4. $\mathrm{PL}$ spectra of $\mathrm{ZnO} / \mathrm{P} 25$ composites calcined at $500{ }^{\circ} \mathrm{C}$ with various $\mathrm{ZnO}$ loadings (a) and $0.5 \% \mathrm{ZnO} / \mathrm{P} 25$ calcined at various temperatures (b); Time-dependent photocurrents of P25 and 0.5\%ZnO/P25-500 electrodes under an on-off UV exposure pulse of $100 \mathrm{~s}(\lambda \leq 400 \mathrm{~nm})$ (c). 

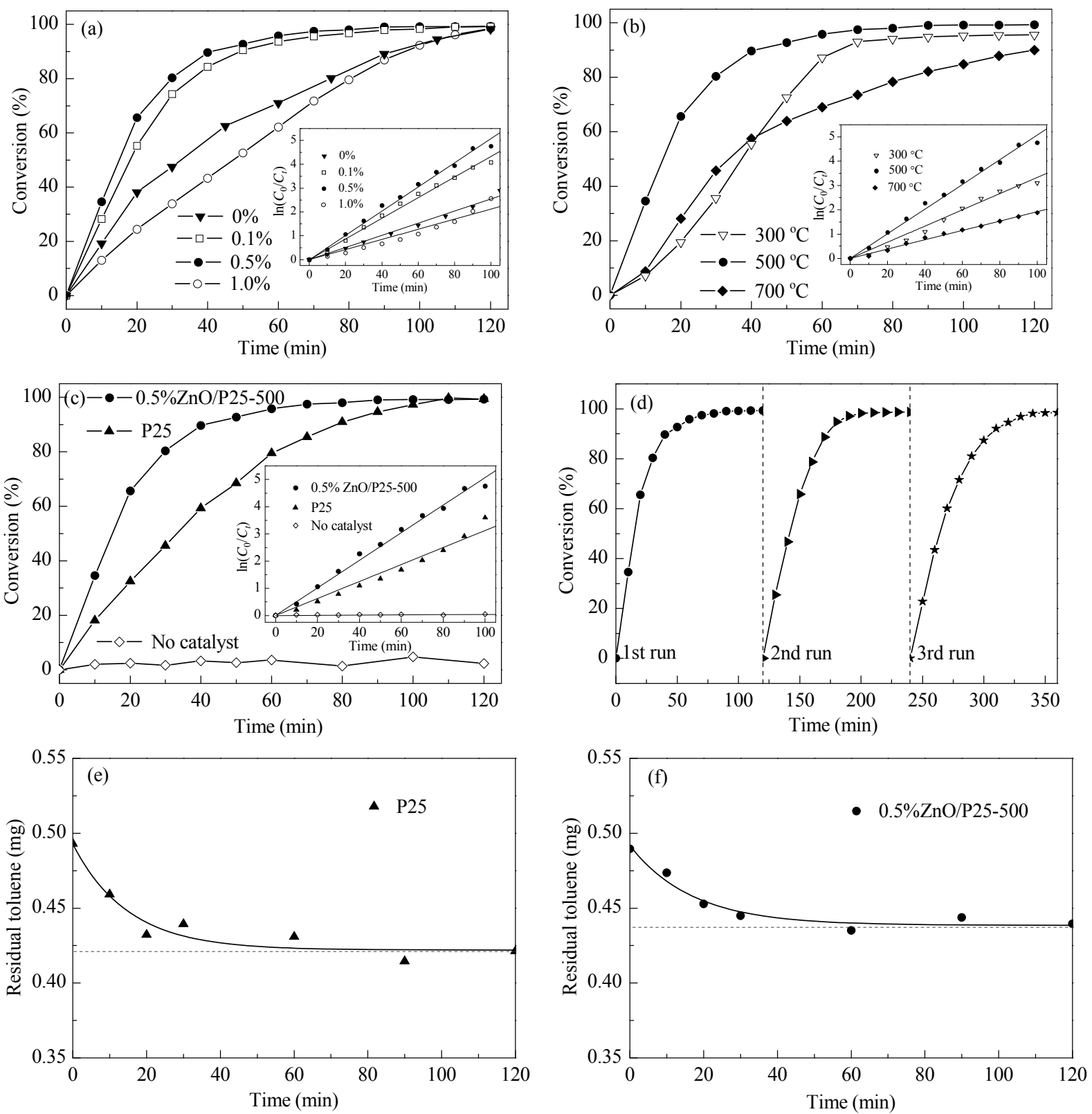

Fig. 5. UV-light photocatalytic decomposition of toluene over different catalysts at $30^{\circ} \mathrm{C}$. (a) ZnO/P25 composites calcined at $500{ }^{\circ} \mathrm{C}$ with various $\mathrm{ZnO}$ loadings; (b) 0.5\% ZnO/P25 calcined at various temperatures; (c) Commercial P25, 0.5\%ZnO/P25-500 and blank test without photocatalyst; (d) Cyclic stability test of $0.5 \% \mathrm{ZnO} / \mathrm{P} 25-500$; (e,f) Adsorption of toluene over commercial P25 and $0.5 \% \mathrm{ZnO} / \mathrm{P} 25-500$ at $30^{\circ} \mathrm{C}$ without light illumination.

Fig. 5(b) displays the toluene decomposition rate over $0.5 \% \mathrm{ZnO} / \mathrm{P} 25$ calcined at various temperatures. As shown, $0.5 \% \mathrm{ZnO} / \mathrm{P} 25-500$ shows higher photocatalytic activity than the $0.5 \% \mathrm{ZnO} / \mathrm{P} 25$ samples calcined at 300 and $700{ }^{\circ} \mathrm{C}$. The performance of 0.5\%ZnO/P25-500 and commercial P25 was compared. As shown in Fig. 5(c), 0.5\%Zn0/P25-500 presents a higher toluene conversion efficiency in comparison with P25, with a $\sim 100 \%$ toluene conversion over $0.5 \% \mathrm{ZnO} / \mathrm{P} 25-500$ in comparison with $\sim 90 \%$ over P25 after irradiation for $80 \mathrm{~min}$. Besides, no obvious toluene degradation was observed under UV-light without a photocatalyst present during the 2-h reaction time, indicating that the gaseous toluene degradation can be ignored. To make a quantitative photocatalytic activity comparison among these samples, the reaction process was analyzed using pseudo-first order reaction kinetics, and the corresponding reaction rate constant was regressed from the $\ln \left(C_{0} / C_{t}\right)$ versus $t$ plot for each sample, as plotted in the insets of Fig. $5(\mathrm{a}-\mathrm{c})$. The as-regressed reaction rate constants for $0.5 \% \mathrm{ZnO} / \mathrm{P} 25-500$ and P25 are $0.051\left(R^{2}=0.99\right)$ and 0.031 $\min ^{-1}\left(R^{2}=0.99\right)$, respectively, indicating the higher degradation rate of $0.5 \% \mathrm{ZnO} / \mathrm{P} 25-500$.

The cyclic stability of $0.5 \% \mathrm{ZnO} / \mathrm{P} 25-500$ is shown in Fig. $5(d)$, and there is no obvious decrease in toluene conversion after UV-light irradiation for $2 \mathrm{~h}$ over 3 cycles, indicating the good stability of $0.5 \% \mathrm{ZnO} / \mathrm{P} 25-500$. Finally, the toluene adsorption curves over commercial P25 and 0.5\%ZnO/P25-500 were measured under the same initial toluene concentration used in the photocatalytic evaluation experiments at $30{ }^{\circ} \mathrm{C}$ as a 
reference, and are shown in Fig. 5(e) and (f). The equilibrium toluene adsorption amount over commercial P25 is approximately $0.35 \mathrm{mg} / \mathrm{g}$ and is approximately $0.27 \mathrm{mg} / \mathrm{g}$ over 0.5\%ZnO/P25-500.

\subsection{Discussion}

When minor $\mathrm{ZnO}$ is loaded over P25, the heterojunction is formed, which may reduce the recombination probability of photo-induced electrons and holes by the internal electric field and thus lead to a high quantum yield. The photo-induced charges separation efficiency strongly depends on the band-edge positions of the two semiconductors. The conduction band (CB) and valence band (VB) potentials of $\mathrm{ZnO}$ and P25 at the point of zero charge can be calculated by the following empirical equation [33]:

$$
E_{\mathrm{VB}}=X-E^{\mathrm{e}}+0.5 E_{\mathrm{g}}
$$

where $E_{\mathrm{VB}}$ is the $\mathrm{VB}$ edge potential, $X$ is the electronegativity of the semiconductor, which is the geometric mean of the electronegativity of the constituent atoms. Herein, the electronegativity of an atom is the arithmetic mean of the atomic electron affinity and the first ionization energy, rather than the common definition of the term. $E^{\mathrm{e}}$ is the energy of free electrons on the hydrogen scale $(\sim 4.5 \mathrm{eV}), E_{\mathrm{g}}$ is the band gap energy of the semiconductor, and $E_{\mathrm{CB}}$ can be determined by $E_{\mathrm{CB}}=E_{\mathrm{VB}}-E_{\mathrm{g}}$. The $X$ values for $\mathrm{ZnO}$ and P25 are approximately 5.67 and $5.83 \mathrm{eV}$, respectively [34]. Using the equation above, the top valence band and the bottom conduction band were calculated to be 2.72 and $-0.38 \mathrm{eV}$ for $\mathrm{ZnO}$, and 2.91 and $-0.25 \mathrm{eV}$ for P25, respectively.

Because both $\mathrm{ZnO}$ and P25 can be excited by UV light, the photocatalytic reaction can be initiated by the absorption of UV-light photons with energy equal to or higher than the band gap, resulting in the creation of photo-induced holes in the VB and electrons in the $\mathrm{CB}$ in both $\mathrm{ZnO}$ and $\mathrm{P} 25$. According to the band-edge position, the photo-induced electrons in the CB of $\mathrm{ZnO}$ can be easily transferred to that of P25, and the simultaneous holes in the VB of P25 can be transferred to that of $\mathrm{ZnO}$ under induction by the internal electric field (Scheme 1). Hence, most of photo-induced electrons and holes are spatially separated from each other, leading to an increased lifetime of the charge carriers and an enhanced interfacial charge transfer to adsorbed organic molecules [14], which is consistent with the optical characterization analysis presented above. These separated electrons in the $\mathrm{CB}$ of both $\mathrm{ZnO}$ and $\mathrm{P} 25$ can reduce the oxygen adsorbed on the photocatalyst to $\mathrm{HOO}$ - because the CB minimum is located at a more negative potential $(-0.38 /-0.25 \mathrm{eV})$ than the electrochemical potential of the desired reaction $\left(\mathrm{O}_{2} / \mathrm{HOO}=-0.05 \mathrm{eV}, \mathrm{O}_{2} / \mathrm{O}_{2}{ }^{--}=-0.33 \mathrm{eV}\right)$ [35]. While the separated holes in the VB maximum of both $\mathrm{ZnO}$ $(2.72 \mathrm{eV})$ and P25 (2.91 eV) can oxidize either the pollutant directly or hydroxyl/water to produce $\mathrm{OH} \cdot$ radicals with oxidation potentials $\left(\cdot \mathrm{OH} / \mathrm{OH}^{-}=1.89 \mathrm{eV}, \cdot \mathrm{OH} / \mathrm{H}_{2} \mathrm{O}=2.72 \mathrm{eV}\right)$ [36]. All these $\mathrm{HOO} \cdot, \cdot \mathrm{OH}$ and holes can participate in the photocatalytic reactions to decompose organic compounds, such as toluene, which leads to the enhanced photocatalytic activity of $0.5 \% \mathrm{ZnO} / \mathrm{P} 25-500$ in comparison with P25. Actually, P25 is composed of $\mathrm{ATiO}_{2}$ and $\mathrm{RTiO}_{2}$, and $\mathrm{ZnO} / \mathrm{ATiO}_{2} / \mathrm{RTiO}_{2}$ junctions are formed in ZnO/P25 (Fig. 2). The band-edge positions and the proposed electron-hole pair separation of $\mathrm{ZnO} / \mathrm{ATiO}_{2} /$ $\mathrm{RTiO}_{2}$ heterojunctions are also shown in Scheme 1. Here, the $E_{\mathrm{g}}$ values of $\mathrm{ATiO}_{2}(\sim 3.20 \mathrm{eV})$ and $\mathrm{RTiO}_{2}(\sim 3.03 \mathrm{eV})$ were taken from the literature [37]. Owing to the difference in the CB and VB positions among these three phases, photo-induced electrons and holes are spatially separated from each other efficiently. Photo-induced holes on the $\mathrm{VB}$ of $\mathrm{ATiO}_{2}$ can transfer to the $\mathrm{VB}$ of $\mathrm{ZnO}$ and $\mathrm{RTiO}_{2}$, and the photo-induced electrons on the $\mathrm{CB}$ of $\mathrm{ZnO}$ can transfer to the $\mathrm{CB}$ of $\mathrm{ATiO}_{2}$ and $\mathrm{RTiO}_{2}$. The multichannel electrons/holes transfer and separation formed in the $\mathrm{ZnO} / \mathrm{ATiO}_{2} / \mathrm{RTiO}_{2}$ heterojunctions leads to the efficient photo-induced charge separation in $\mathrm{ZnO} / \mathrm{P} 25$.

This proposed multichannel charge separation process and its promotion to the performance of $\mathrm{ZnO} / \mathrm{P} 25$ heterojunctions can well explain the results obtained in this work. Although the BET surface area and equilibrium toluene adsorption amount of commercial P25 (55 m²/g and ca. $0.35 \mathrm{mg} / \mathrm{g}$ ) are higher than those of $0.5 \% \mathrm{ZnO} / \mathrm{P} 25-500\left(39 \mathrm{~m}^{2} / \mathrm{g}\right.$ and ca. $\left.0.27 \mathrm{mg} / \mathrm{g}\right)$, the photocatalytic activity of $0.5 \% \mathrm{ZnO} / \mathrm{P} 25-500$ developed in this work is still high, indicating that the multichannel charge separation promotion effect prevails. Generally speaking, the crystallinity and the interaction among the composed phases can be improved at a high calcination temperature, which is beneficial for charge separation. Thus, the PL spectra of $0.5 \% \mathrm{ZnO} / \mathrm{P} 25$ calcined at various temperatures (Fig. 4(b)) indicate the better

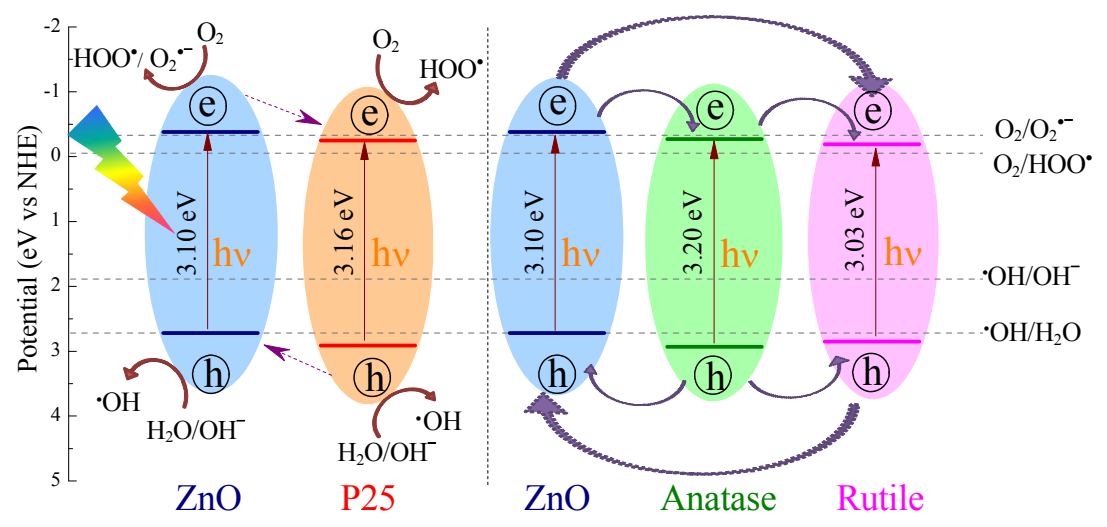

Scheme 1. Diagram for the band levels and the proposed electron-hole pair separation of ZnO/P25 heterojunctions. 
charge separation in $0.5 \% \mathrm{ZnO} / \mathrm{P} 25-500$ than that of $0.5 \% \mathrm{ZnO} /$ P25-300. However, when the calcination temperature was raised to $700{ }^{\circ} \mathrm{C}$, a poorer charge separation over $0.5 \% \mathrm{ZnO} /$ P25-700 than that over 0.5\%ZnO/P25-500 was observed. Owing to the almost complete transformation from $\mathrm{ATiO}_{2}$ to $\mathrm{RTiO}_{2}$ and from the triple-phase $\mathrm{ZnO} / \mathrm{ATiO}_{2} / \mathrm{RTiO}_{2}$ junctions to the dual-phase $\mathrm{ZnO} / \mathrm{RTiO}_{2}$ junctions, the multichannel charge separation in $0.5 \% \mathrm{ZnO} / \mathrm{P} 25-700$ is suppressed, leading partly to its lower quantum yield and photocatalytic activity compared with that of $0.5 \% \mathrm{ZnO} / \mathrm{P} 25-500$. The loading of $\mathrm{ZnO}$ also exerts an important effect on the formation and function of the $\mathrm{ZnO} / \mathrm{ATiO}_{2} / \mathrm{RTiO}_{2}$ heterojunctions. With an appropriate $\mathrm{ZnO}$ loading, that is, $0.5 \% \mathrm{ZnO} / \mathrm{P} 25-500$, the as-formed $\mathrm{ZnO} / \mathrm{ATiO}_{2} /$ $\mathrm{RTiO}_{2}$ heterojunctions and multichannel charge separation process can effectively improve the charge separation and the photocatalytic performance of the $\mathrm{ZnO} / \mathrm{P} 25$ composite. In the case of the catalyst with a high amount of $\mathrm{ZnO}$, that is, $1.0 \% \mathrm{ZnO} / \mathrm{P} 25-500$, the properties of bulk $\mathrm{ZnO}$ may dominate the surface properties of the $\mathrm{ZnO} / \mathrm{P} 25$ composite, and the promotion to the charge separation and photocatalytic performance by the surface heterojunctions is suppressed. Kim et al. [21] also reported that the photocatalytic properties decreased as the thickness of the $\mathrm{ZnO}$ layer increased in the $\mathrm{ZnO} / \mathrm{TiO}_{2}$ nanoporous films. In contrast, lower amounts of $\mathrm{ZnO}$ cannot effectively modify the P25 surface to form effective heterojunctions. These aspects suggest that the optimum $\mathrm{ZnO}$ addition amount to enhance the properties of $\mathrm{ZnO} / \mathrm{P} 25-500$ is around $0.5 \mathrm{wt} \%$. Therefore, we can see that the modification of P25 by minor $\mathrm{ZnO}$ can effectively improve the photo-induced charge separation and photocatalytic properties of toluene degradation by the formation of $\mathrm{ZnO} / \mathrm{ATiO}_{2} / \mathrm{RTiO}_{2}$ heterojunctions and multichannel electron/hole transfer and separation.

\section{Conclusions}

Zn0/P25 composites were synthesized by a facile incipient wetness impregnation method and evaluated for the photocatalytic removal of gaseous toluene. The $\mathrm{ZnO} / \mathrm{P} 25$ composites consist of anatase $\mathrm{TiO}_{2}\left(\mathrm{ATiO}_{2}\right)$, rutile $\mathrm{TiO}_{2}\left(\mathrm{RTiO}_{2}\right)$ and hexagonal zincite structures. The parasitic phase of $\mathrm{ZnO}$ in P25 led to the formation of $\mathrm{ZnO}(002) / \mathrm{ATiO}_{2}(101) / \mathrm{RTiO}_{2}(110)$ heterojunctions and enhanced light absorption. The multichannel electron/hole separation in the as-formed heterojunctions remarkably improved the photo-induced charge separation. Toluene was completely oxidized into $\mathrm{CO}_{2}$ over $\mathrm{ZnO} / \mathrm{P} 25$ composites under UV light irradiation $(\lambda \leq 400 \mathrm{~nm})$ and ambient temperature. In comparison with commercial P25, 0.5\%ZnO/P25 calcined at $500{ }^{\circ} \mathrm{C}$ showed remarkably enhanced photocatalytic activity owing to the effective electron-hole separation at the interfaces of the heterojunctions. Hence, the modification of P25 by minor $\mathrm{ZnO}$ can efficiently improve the photo-induced charge separation and photocatalytic properties for toluene degradation by the heterojunctions formation and multichannel electron/hole transfer and separation.

\section{References}

[1] D. A. Sarigiannis, S. P. Karakitsios, A. Gotti, I. L. Liakos, A. Katsoyiannis, Environ. Int., 2011, 37, 743-765.

[2] W. Z. Wang, H. L. Wang, T. L. Zhu, X. Fan, J. Hazard. Mater., 2015, 292, 70-78.

[3] Z. B. Rui, L. Y. Chen, H. Y. Chen, H. B. Ji, Ind. Eng. Chem. Res., 2014, 53, 15879-15888.

[4] Z. B. Rui, C. Y. Chen, Y. B. Lu, H. B. Ji, Chin. J. Chem. Eng., 2014, 22, 882-887.

[5] C. Y. Chen, F. Chen, L. Zhang, S. X. Pan, C. Q. Bian, X. M. Zheng, X. Q. Meng, F. S. Xiao, Chem. Commun., 2015, 51, 5936-5938.

[6] H. Einaga, S. Futamura, T. Ibusuki, Appl. Catal. B, 2002, 38, 215-225.

[7] M. J. Wang, F. Zhang, X. D. Zhu, Z. M. Qi, B. Hong, J. J. Ding, J. Bao, S. Sun, C. Gao, Langmuir, 2015, 31, 1730-1736.

[8] A. L. Linsebigler, G. Q. Lu, J. T. Yates, Chem. Rev., 1995, 95, 735-758.

[9] J. Zhang, Q. Xu, Z. C. Feng, M. J. Li, C. Li, Angew. Chem. Int. Ed., 2008, 47, 1766-1769.

[10] D. C. Hurum, A. G. Agrios, K. A. Gray, T. Rajh, M. C. Thurnauer, J. Phys. Chem. B, 2003, 107, 4545-4549.

[11] H. X. Li, Z. F. Bian, J. Zhu, Y. N. Huo, H. Li, Y. F. Lu, J. Am. Chem. Soc., 2007, 129, 4538-4539.

[12] W. J. Dai, J. Q. Yan, K. Dai, L. D. Li, N. J. Guan, Chin. J. Catal., 2015, 36, 1968-1975.

[13] C. L. Yu, W. Q. Zhou, J. C. Yu, H. Liu, L. F. Wei, Chin. J. Catal., 2014, 35, 1609-1618.

[14] R. Marschall, Adv. Funct. Mater., 2014, 24, 2421-2440.

[15] Y. H. Zhang, Z. R. Tang, X. Z. Fu, Y. J. Xu, ACS Nano, 2010, 4, 7303-7314.

\section{Graphical Abstract}

Chin. J. Catal., 2016, 37: 869-877 doi: 10.1016/S1872-2067(15)61093-2

Multichannel charge separation promoted $\mathrm{ZnO} / \mathrm{P25}$ heterojunctions for the photocatalytic oxidation of toluene

Jiejing Kong, Xiaodong Lai, Zebao Rui*, Hongbing Ji*, Shengfu Ji Sun Yat-sen University; Beijing University of Chemical Technology

The parasitic phase of $\mathrm{ZnO}$ in $\mathrm{P} 25$ leads to the formation of $\mathrm{ZnO}(002) / \mathrm{ATiO}_{2}(101) / \mathrm{RTiO}_{2}(110)$ heterojunctions. This multichannel electron/hole separation in the as-formed heterojunction remarkably improves the photoinduced charge separation and its photocatalytic performance.

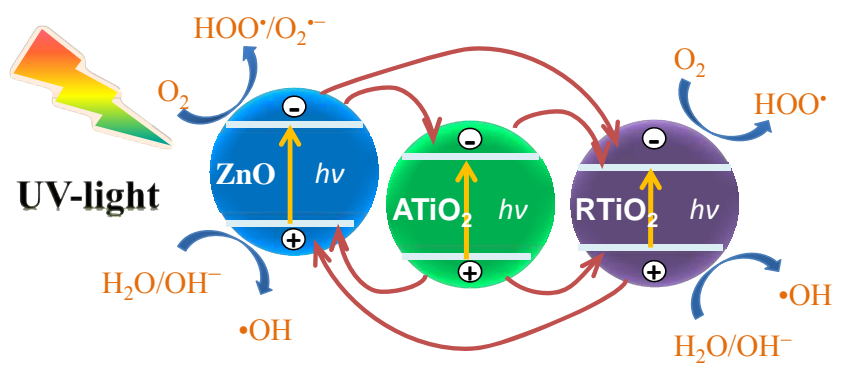


[16] N. Qin, Y. H. Liu, W. M. Wu, L. J. Shen, X. Chen, Z. H. Li, L. Wu, Langmuir, 2015, 31, 1203-1209.

[17] N. Siedl, S. O. Baumann, M. J. Elser, O. Diwald, J. Phys. Chem. C, 2012, 116, 22967-22973.

[18] C. L. Yu, L. F. Wei, J. C. Chen, Y. Xie, W. Q. Zhou, Q. Z. Fan, Ind. Eng. Chem. Res., 2014, 53, 5759-5766.

[19] Y. Wang, Y. Z. Zheng, S. Q. Lu, X. Tao, Y. K. Che, J. F. Chen. ACS Appl. Mater. Interfaces, 2015, 7, 6093-6101.

[20] J. Wang, X. L. Liu, A. L. Yang, G. L. Zheng, S. Y. Yang, H. Y. Wei, Q. S. Zhu, Z. G. Wang, Appl. Phys. A, 2010, 103, 1099-1103.

[21] D. W. Kim, S. Lee, H. S. Jung, J. Y. Kim, H. Shin, K. S. Hong, Int. J. Hydrogen Energy, 2007, 32, 3137-3140.

[22] Y. Z. Lei, G. H. Zhao, M. C. Liu, Z. N. Zhang, X. L. Tong, T. C. Cao, J. Phys. Chem. C, 2009, 113, 19067-19076.

[23] D. Chen, H. Zhang, S. Hu, J. H. Li, J. Phys. Chem. C, 2008, 112, 117-122.

[24] F. X. Xiao, ACS Appl. Mater. Interfaces, 2012, 4, 7055-7063.

[25] L. Wu, J. Xing, Y. Hou, F. Y. Xiao, Z. Li, H. G. Yang, Chem.-Eur. J., 2013, 19, 8393-8396.

[26] T. Kawahara, Y. Konishi, H. Tada, N. Tohge, J. Nishii, S. Ito, Angew. Chem. Int. Ed., 2002, 41, 2811-2813.
[27] D. A. H. Hanaor, C. C. Sorrell, J. Mater. Sci, 2011, 46, 855-874.

[28] Z. B. Rui, Y. F. Huang, Y. Zheng, H. B. Ji, X. Yu, J. Mol. Catal. A, 2013, 372, 128-136.

[29] B. Ohtani, O. O. Prieto-Mahaney, D. Li, R. Abe, J. Photochem. Photobiol. A, 2010, 216, 179-182.

[30] J. M. Gallardo Amores, V. Sanchez Escribano, G. Buscab, J. Mater. Chem. 1995, 5, 1245-1249.

[31] F. Qin, H. P. Zhao, G. F. Li, H. Yang, J. Li, R. M. Wang, Y. L. Liu, J. C. Hu, H. Z. Sun, R. Chen, Nanoscale, 2014, 6, 5402-5409.

[32] H. F. Cheng, B. B. Huang, Y. Dai, X. Y. Qin, X. Y. Zhang, Langmuir, 2010, 26, 6618-6624.

[33] Z. F. Jiang, D. L. Jiang, Z. X. Yan, D. Liu, K. Qian, J. M. Xie, Appl. Catal. $B$, 2015, 170-171, 195-205.

[34] C. W. Kwon, A. Poquet, S. Mornet, G. Campet, M. H. Delville, M. Treguer, J. Portier, Mater. Lett., 2001, 51, 402-413.

[35] W. Y. Teoh, J. A. Scott, R. Amal, J. Phys. Chem. Lett., 2012, 3, 629-639.

[36] T. Tachikawa, M. Fujitsuka, T. Majima, J. Phys. Chem. C, 2007, 111, 5259-5275.

[37] L. Miao, P. Jin, K. Kaneko, A. Terai, N. Nabatova-Gabain, S. Tanemura, Appl. Surf. Sci., 2003, 212-213, 255-263.

\title{
具有多通道载流子分离功能的 $\mathrm{ZnO} / \mathrm{P25}$ 异质结构光催化氧化甲苯
}

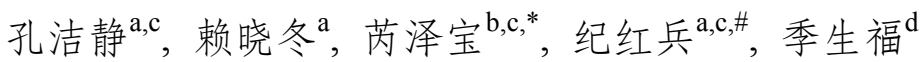 \\ ${ }^{\mathrm{a}}$ 中山大学化学与化学工程学院, 广东广州 510275 \\ ${ }^{\mathrm{b}}$ 中山大学化学工程与技术学院, 广东广州 510275 \\ c 中山大学惠州研究院废气净化与控制研发中心, 广东惠州 516081 \\ d 北京化工大学化工资源有效利用国家重点实验室, 北京 100029
}

摘要: 甲苯是一种最常见的室内有毒挥发性有机物 (VOCs), 目前消除方法主要有吸附、催化燃烧和光催化氧化, 其中光催 化是一种最高效和经济可行的方法, 能在较温和条件下将甲苯完全矿化为 $\mathrm{CO}_{2}$. 作为研究最广泛的光催化剂, $\mathrm{TiO}_{2}$ 在应用 中通常有锐铁矿 $\left(\mathrm{ATiO}_{2}\right)$ 和金红石 $\left(\mathrm{RTiO}_{2}\right)$ 两种物相, 但单物相 $\mathrm{TiO}_{2}$ 的低量子产率和光生电子-空穴对的快速复合严重限 制了它的应用. 本文选择兼具锐钛矿和金红石两种物相的 P25 为催化剂载体, 通过负载少量 $\mathrm{ZnO}$ 和构建多组分并具备多 通道载流子分离功能的异质结以提高 $\mathrm{TiO}_{2}$ 基光催化剂的性能.

利用一步浸渍法制备了一系列 $\mathrm{ZnO} / \mathrm{P} 25$ 复合光催化剂, 考察了其光催化降解气相甲苯性能. $\mathrm{X}$ 射线粉末衍射结果表 明, $\mathrm{ZnO} / \mathrm{P} 25$ 异质光催化剂是由 $\mathrm{ATiO}_{2}, \mathrm{RTiO}_{2}$ 和红锌矿三种物相结构组成. 高分辨透射电镜结果表明, $\mathrm{ZnO} / \mathrm{P} 25$ 具备三相 异质结 $\mathrm{ZnO}(002) / \mathrm{ATiO}_{2}(101) / \mathrm{RTiO}_{2}(110)$. 紫外可见光谱、荧光光谱和光电流表征结果表明, $\mathrm{ZnO} / \mathrm{P} 25$ 所形成的三相异质结 不但增强了光吸收能力, 还实现了多通道电子/空穴分离. 催化降解实验表明, $\mathrm{ZnO} / \mathrm{P} 25$ 异质光催化剂能在室温紫外光辐射 下将甲苯完全矿化为 $\mathrm{CO}_{2}$ 和 $\mathrm{H}_{2} \mathrm{O}$. 基于三相异质结和多通道光生电子-空穴对分离的形成及促进作用, $\mathrm{ZnO} / \mathrm{P} 25$ 光催化活 性和速率均明显高于 P25. 本文报道的多通道载流子分离理念可为高效光催化剂设计和应用提供一种新思路.

关键词: 二氧化钛；氧化锌；甲苯；光催化；异质结；多通道载流子分离

收稿日期: 2016-01-22. 接受日期: 2016-03-29. 出版日期: 2016-06-05.

*通讯联系人. 电话: (020)84113663; 电子信箱: ruizebao@mail.sysu.edu.cn

\#通讯联系人. 电话: (020)84113658; 电子信箱: jihb@mail.sysu.edu.cn

基金来源：国家自然科学基金(21576298, 21425627); 广东省科技计划 (2013B090500029); 广东省自然科学基金 (2014A030313135,2014A030308012); 化工资源有效利用国家重点实验室开放基金(CRE-2015-C-301).

本文的英文电子版由Elsevier出版社在ScienceDirect上出版(http://www.sciencedirect.com/science/journal/18722067). 